Butwal Campus Journal, Vol. 3, No. 1: 37-46, July 2020

Research Management Cell, Butwal Multiple Campus, Tribhuvan University, Nepal

\title{
STAKEHOLDERS' PERCEPTION TOWARD RESOURCE MOBILIZATION IN RUPANDEHI
}

\author{
Pramshu Nepal* \\ *Assistant Professor, Butwal Multiple Campus, Butwal, TU
}

Article History: Received 8 May 2020; Reviewed 29 May 2020; Revised 29 June 2020; Accepted 05 July 2020

\begin{abstract}
This paper analyzes the perception of the stakeholders toward resource mobilization in Rupandehi district. Using the questionnaire survey on purposive sample of 80 respondents representing government employees, former officials of LBs, representatives from civil societies and NGOs, and experts on fiscal decentralization and local development, the study reports that many of the stakeholders are not satisfied with the current local resources mobilization practices of Rupandehi district. As the study indicates, there is resource gap in local level to meet the aspiration and demand of people. Thus, the study results show that, in order to mobilize effectively the local resources in development activities, the capacity of local bodies needs to be enhanced.
\end{abstract}

Keywords: capacity development - inclusive participation - local bodies - resources transparency.

\section{INTRODUCTION}

Collection and utilization of resources through any system of governance are prerequisites to achieve the desired goals of the society. Resources are the input that the organization can either convert into products or services or use to increase its own capabilities (Axin, 1978). Resource is an important component to uplift the socio-economic condition of people. Availability of resources may be different in different part of the world; however, in any forms or types it is available everywhere at local level. Particular types of resources may available in particular place, such resources need to be utilized combining with other resources 
in appropriate proportion to produce something. Otherwise the resources remain idle. Production of something can enhance the socio-economic condition of the people, because idle resource does not possess utility. The identification and utilization of available resources in appropriate proportion is a greater challenge.

An appropriate fiscal structure is crucial for ensuring adequacy of total local resources and significant autonomy should be exercised in generating resources from local sources. For this, broader based revenue instruments should be made available to local bodies. Adoption of a particular instrument and the selection of an approved rate structure should be at the discretion of the local government and the revenue generated should be available for general local expenditures. The other basic idea of fiscal decentralization is that local governments should be assigned stable sources of revenue. Local taxes should also be easy to administer and it should be easy to separate the tax base between different local bodies. Also, it is preferable if local taxes broadly correspond to the benefits received by local residents from local government services.

Autonomy in the revenue side is not always desirable. It has side effects, as well. Revenue decentralization often causes increased sub-national fiscal inequality - with wealthier regions being able to collect more revenues than poorer ones (Jutting et al, 2005). In these cases, equalization grants or other intergovernmental fiscal transfer schemes become necessary to ensure that sub-national governments have adequate revenues to fulfill their expenditure responsibilities. Resources should thus come from both the central government and local taxes. Similarly, local taxation is not an appropriate instrument for income redistribution (Boex et al, 2006). If local taxes are not designed well and adopted necessary measures, these taxes aggravate the situation. The other side of the local taxation is its regressiveness. If the local tax is regressive, then it directly affects the distribution of disposable income of the taxpayers. Taxes such as indirect taxes and property taxes are common among sub-national governments which are regressive or less progressive in nature. In this context, a greater reliance on sub-national tax collection might reduce the progressivity of the tax system at the national level (Sepulveda and Vazquez, 2010).

In the light of cited issues, this study attempt to examine the perception of stakeholders toward resource mobilization in Rupandehi district of Nepal. The rest of this paper is organized as follows: section two describes research methods; section three presents survey results and discussion on findings; and finally, section four concludes the study. 


\section{RESEARCH METHODS}

In this study, Rupandehi district has been selected purposively for field survey. Descriptive nature of research design was adopted to meet the objectives. As reported in Table 1 , a total of 80 respondents were selected for interview.

Table 1: Number of respondents from each sampled level

\begin{tabular}{|c|c|c|c|c|c|}
\hline Respondents & District & $\begin{array}{l}\text { Rural } \\
\text { Municipality }\end{array}$ & Municipality & Total & Sector \\
\hline $\begin{array}{l}\text { Government } \\
\text { officials }\end{array}$ & 10 & 10 & 5 & 25 & $\begin{array}{l}\text { Government } \\
\text { Employees working } \\
\text { at district including } \\
\text { DDC, RMs and } \\
\text { Municipalities }\end{array}$ \\
\hline $\begin{array}{l}\text { Former officials } \\
\text { of LGs }\end{array}$ & 8 & 7 & 5 & 20 & $\begin{array}{l}\text { Those persons who } \\
\text { have ever worked at } \\
\text { LGs as peoples' } \\
\text { representatives }\end{array}$ \\
\hline $\begin{array}{l}\text { Representatives } \\
\text { of developments, } \\
\text { political parties, } \\
\text { NGO and civil } \\
\text { societies }\end{array}$ & 10 & 8 & 7 & 25 & $\begin{array}{l}\text { Those who are } \\
\text { working within the } \\
\text { Rupandehi district. }\end{array}$ \\
\hline $\begin{array}{l}\text { Expert at local } \\
\text { development, } \\
\text { fiscal } \\
\text { decentralization, } \\
\text { planning, etc. }\end{array}$ & 10 & - & - & 10 & $\begin{array}{l}\text { Those who are } \\
\text { either within the } \\
\text { Rupandehi or } \\
\text { outside Rupandehi } \\
\text { district. }\end{array}$ \\
\hline
\end{tabular}

\begin{tabular}{lrrrr}
\hline Total & 38 & 25 & 17 & 80 \\
\hline Source: Field survey, 2019 & & &
\end{tabular}

Due to the nature of the study, it was presumed that not all the local residents have knowledge on the fiscal decentralization and performance of the local bodies (LBs). So, the possible respondents were grouped into four categories such as government employees, former officials of LBs, representatives of the NGOs, civil societies, etc. and experts on fiscal decentralization and local development to survey their opinion on resource mobilization in Rupandehi district. For the purpose of study, 10 to 25 respondents, as shown in Table 1, were 
selected from each group purposively. The respondents were further stratified on three levels, i.e. district, municipalities and rural municipalities (RMs).

\section{SURVEY RESULTS AND DISCUSSION}

This section presents the results of questionnaire survey among 80 respondents selected purposively for the study. A set of questionnaire was prepared and distributed to major stakeholders in Rupandehi district to understand the perception of the key stakeholders on local resource mobilization in Rupandehi district. Moreover, the study also used meeting and discussion with some elected president and vice president of local bodies of Rupandehi district to obtain information for the study. The survey results are reported and discussed in the following section.

\section{Corrective ways for resource mobilization at local level}

Respondents shared constructive and useful experience on corrective ways for resource mobilization at local level. On the basis of the opinion expressed by respondents, some key points have been made. As indicated by respondents, although there is resource gap in local level to meet the aspiration and demand of people, Local Body Fiscal Commission has been able to carry out the study on revenue potentiality at local level and identified some new areas of sources of revenue for the local government bodies. Similarly, the concern of accountability, transparency and responsibility of local government bodies has got high priority for the quality and timely service delivery to the people. It is said the pattern of local resource mobilization is in the learning stage but it is necessary to reach to the earning stage so that the resource gap will be minimized. As stated by respondents, the new areas of local resource mobilization need to be identified because local bodies are highly dependent on the grants from Government of Nepal (GoN). The GoN should not intervene time and again in the areas of mobilizing local resources. It is pre-condition that there should be responsible representatives in local government bodies to respect democratic norms and value and for effective service delivery, resource mobilization. Further, it is necessary to maintain transparency and inclusive participation in resource mobilization and decision making process.

\section{Role of GoN and local bodies for effective resource mobilization at local level}

As pointed out by the respondents, the GoN should carry out study and research to identify the potential new sources of resource mobilization at local level. In order to properly 
implement the fiscal decentralization process, the fiscal autonomy needs to be devolved to local level. New laws on revenue collection, sharing and mobilization need to be promulgated as and when needed. The Government of Nepal has to transfer certain authority to collect local tax at local level. The mega projects that create employment and generate local tax need to be implemented by the Government of Nepal. There should be cordial relationship between Ministry of Local Development and Ministry of Forest and Soil Conservation for the mobilization and utilization of natural resources for the economic development of the country. The local government bodies themselves be proactive to identify the new sources of revenue at the local level. Expert person should be included in planning process, decision making process, resource mobilization and utilization.

\section{Problems in resource mobilization at local level}

Respondents think that the local government bodies are not autonomous to utilize own internal revenue in their discretion. There is no proper coordination and support from the local administration to local government bodies for resource mobilization. The role of political parties in resource mobilization should be positive and constructive. It is difficult to prepare actual annual program and budget due to the un-certainty of amount to be received by the central level by the revenue sharing from forest, tourism, electrification and registration. Local Bodies have not prepared clear policy for resource mobilization at district level. The increment of illegal import and export of local productions has hampered to generate new sources of income at local level. There is no mutual understanding about resource mobilization among NGOs, CBOs and local bodies (Lamichhane, 2011).

\section{Problems in receiving the fund from revenue sharing by local bodies}

The Local bodies of Rupandehi received certain amount of revenue from forest, tourism, electrification and land registration. However, there is uncertainty and delay in receiving amount by the local bodies from concerned agencies of forest, tourism, electrification and registration. The concerned agencies are reluctant to make the fixed amount of revenues sharing available to local bodies easily. It is not a good practice to receive junk amount of money in the last month of the fiscal year from center in the name of capital expenditure. It has created a serious problem to use the money in proper way and in right place. As a result, it has played a crucial role to make big volume of advance amount of local bodies. The legal provision to use the amount received by local bodies from the revenue sharing heading is not much pragmatic. The compulsion is that local bodies have to utilize 
certain percentage of the amount in the same area from where revenue is received by local bodies.

\section{Focused areas for the effective resource mobilization by local bodies}

For effective use of legal provisions, institutional capacity needs to be strengthened. In order to mobilize effectively the local resources in development activities, the capacity of local bodies needs to be enhanced. The capacity of local bodies means the full fledged local bodies including public representatives, equipped and trained human resources. Although there is provision of forecasting of the local revenue by the local government bodies, the provision is not properly followed at the local level. It is more specifically argued that the fiscal autonomy of fixing rate and base of local taxes should be given to the local government by constitution.

\section{Problems of fund transfer system of GoN}

Center grant transfer system emphasizes process rather than output of the service delivered by the local government. The Government of Nepal does not provide grant in line with the approved annual program and budget by the respective local government council. Formula based grant system of Government of Nepal should be effective. It is necessary to discourage the process of formulating plans based on access and power of certain groups of the society. There should be special treatment for the local bodies having very low internal revenue. Although the sources of local bodies are increasing year by year, there still exist some core problems such as weak institutional capacity of local bodies to collect and use the resources. Moreover, there is no good monitoring and motivation mechanism of the programs and projects implemented at the local level. There is no scientific and practical forecasting system of revenue for coming fiscal year at local level.

\section{Capacity development areas of local bodies in resource mobilization}

Although there is a Revenue Section in every local body to look after all the activities related to the revenue forecasting, collection and its utilization, it is not functional properly due to the lack of sufficient capable responsible persons. Moreover, due to the absence of responsible representatives, local government bodies have neither seriously taken their ownership nor given leadership. It is urgent that there should be strong inter sections coordination between revenue section, account section, internal audit section, and planning section for effective functioning of each section within local bodies. Furthermore, necessary 
training and orientation program must be conducted focusing local bodies' personnel, representatives of all party mechanism and user group etc. In fact, local bodies' staffs are not mentally prepared to work independently to identify the new sources of revenue at the district level because of the political instability in the country since long ago. So, time has come to increase support for the human resource and physical infrastructure development for the quality of service from the local government bodies. The public private partnership would be a good instrument to mobilize more resources in the district level.

\section{Perception of the stakeholders}

Perceptions of the stakeholder of Rupandehi district in regards to the fiscal decentralization and local resource mobilization are presented in the Table 2 through 6 .

Table 2 reports the opinion of respondents as they perceived on internal resource mobilization in Rupandehi district. As the results indicate, 75 stakeholders (that is, $93.75 \%$ ) are not satisfied with the internal resource mobilization practiced by local bodies. Similarly, vast majority of the stakeholders (i.e. 75 percent) know about the formulation of revenue policy of local bodies. Moreover, all of the stakeholders think that local bodies cannot collect the revenue according to the expectation. Finally, all of them indicate that they are not satisfied with the central government transfer system.

Table 2: Internal resource mobilization

\begin{tabular}{llccc}
\hline \multicolumn{1}{c}{ Questions } & \multicolumn{3}{c}{ Opinion of the Stakeholder } \\
\cline { 2 - 4 } & \multicolumn{1}{c}{ Yes } & No & Don't know \\
\hline I. & $\begin{array}{l}\text { Are you satisfied with the practice of } \\
\text { internal resource mobilization by LBs? }\end{array}$ & 5 & 75 & \\
II. $\begin{array}{l}\text { Do your local bodies formulate own } \\
\text { revenue policy? }\end{array}$ & 60 & 80 \\
III. Does your local body collect revenue \\
$\begin{array}{l}\text { according to expectation? } \\
\text { Are you satisfied with the central } \\
\text { government transfer system? }\end{array}$
\end{tabular}
Source: Field survey, 2019

Table 3 reports the opinion of stakeholders on the role of central and local government in resource mobilization at district level. The result indicates that 40 stakeholders (50\%) have given more focus for cordial relationship between Ministry of Local Development and other concerned ministry for effective resource mobilization at district level. As compared 
to option 'D', stakeholders have given less focus for A, B and C options for effective resource mobilization at district level.

Table 3: Role of central and local government

\begin{tabular}{|c|c|c|c|c|}
\hline \multirow{2}{*}{ Question } & \multicolumn{4}{|c|}{ Opinion of Stakeholder } \\
\hline & $\mathbf{A}$ & B & $\mathrm{C}$ & D \\
\hline $\begin{array}{l}\text { What kinds of role need to } \\
\text { be played by centre and } \\
\text { local government for } \\
\text { resource mobilization at } \\
\text { district level? }\end{array}$ & $\begin{array}{l}\text { Identify new } \\
\text { potential } \\
\text { source of } \\
\text { revenue at } \\
\text { local level. }\end{array}$ & $\begin{array}{l}\text { Autonomy } \\
\text { needs to be } \\
\text { devolved at } \\
\text { local level. }\end{array}$ & $\begin{array}{l}\text { Transfer } \\
\text { certain } \\
\text { authority to } \\
\text { collect tax at } \\
\text { local level. }\end{array}$ & $\begin{array}{l}\text { Cordial } \\
\text { relationship } \\
\text { between different } \\
\text { ministries and } \\
\text { departments. }\end{array}$ \\
\hline & 10 & 15 & 15 & 40 \\
\hline
\end{tabular}

Source: Field survey, 2019

The opinions of stakeholders in the problems faced by local bodies for mobilizing internal revenue are reported in Table 4. As the results indicate, 50 out of 80 stakeholders blamed that political parties' role is not supportive for effective resource mobilization at district level. As compared to option 'C.', stakeholders have given less focus for A, B and D options for problem faced at district level for effective resource mobilization.

Table 4: Problem of local bodies for mobilizing internal revenue

\begin{tabular}{|c|c|c|c|c|}
\hline \multirow{2}{*}{ Question } & \multicolumn{4}{|c|}{ Opinions of the Stakeholders } \\
\hline & $\mathbf{A}$ & B & $\mathrm{C}$ & D \\
\hline \multirow[t]{2}{*}{$\begin{array}{l}\text { What are the problems } \\
\text { faced at local level in } \\
\text { course of mobilization } \\
\text { of internal revenue? }\end{array}$} & $\begin{array}{l}\text { Local } \\
\text { government } \\
\text { bodies are not } \\
\text { autonomous }\end{array}$ & $\begin{array}{l}\text { No coordination } \\
\text { from local } \\
\text { administration to } \\
\text { LGs }\end{array}$ & $\begin{array}{l}\text { Role of } \\
\text { political } \\
\text { parties is not } \\
\text { supportive }\end{array}$ & $\begin{array}{l}\text { Uncertainty } \\
\text { of revenue } \\
\text { sharing from } \\
\text { different } \\
\text { headings }\end{array}$ \\
\hline & 15 & 10 & 50 & 5 \\
\hline
\end{tabular}

Source: Field survey, 2019

Table 5 reports the opinion on the measures for effective mobilization of resources. The results indicate that 55 out of 80 stakeholders have given more focus to enhance the capacity of local bodies for effective resource mobilization at district level. As the respondents think, other options such as fiscal autonomy (option A), role of political parties (option B), and degree of transparency (option C) are less effective measures for resource mobilization at district level in Rupandehi. 
Table 5: Measures for effective mobilization of resources

\begin{tabular}{|c|c|c|c|c|}
\hline \multirow{2}{*}{ Question } & \multicolumn{4}{|c|}{ Opinions of the Stakeholders } \\
\hline & $\mathbf{A}$ & B & $\mathrm{C}$ & D \\
\hline $\begin{array}{l}\text { What are the measures for } \\
\text { effective mobilization of } \\
\text { resources by local bodies? }\end{array}$ & $\begin{array}{l}\text { Capacity of } \\
\text { local bodies } \\
\text { needs to be } \\
\text { enhanced. }\end{array}$ & $\begin{array}{l}\text { Fiscal } \\
\text { autonomy } \\
\text { should be } \\
\text { given to local } \\
\text { bodies. }\end{array}$ & $\begin{array}{lr}\text { Role } & \text { of } \\
\text { political parties } \\
\text { should be } \\
\text { supportive. }\end{array}$ & $\begin{array}{ll}\text { Degrees } & \text { of } \\
\text { transparency } & \\
\text { should } & \text { be } \\
\text { increased. } & \end{array}$ \\
\hline & 55 & 5 & 10 & 10 \\
\hline
\end{tabular}

Source: Field survey, 2019

Finally, Table 6 reports the stakeholders' responses on the areas of capacity development of local bodies for resource mobilization. It indicates that 45 out of 80 stakeholders have suggested that revenue section of LBs should properly function for the effective resource mobilization at district level. As compared to option ' $A$ ', the stakeholders have given less focus for necessary training to local bodies' personnel (option B) and the need to start public-private program (option C) for effective resource mobilization at district level.

Table 6: Areas of capacity development of local bodies

\begin{tabular}{llll}
\hline \multirow{2}{*}{ Question } & \multicolumn{3}{c}{ Opinions of the Stakeholders } \\
\cline { 2 - 4 } & \multicolumn{1}{c}{ A } & \multicolumn{1}{c}{ B } & \multicolumn{1}{c}{ C } \\
\hline $\begin{array}{l}\text { What are the areas of capacity } \\
\text { development of local bodies } \\
\text { for resource mobilization? }\end{array}$ & $\begin{array}{l}\text { Revenue section of } \\
\text { local bodies should } \\
\text { function properly. }\end{array}$ & $\begin{array}{l}\text { Necessary } \\
\text { training must be } \\
\text { provided to local } \\
\text { bodies personnel. }\end{array}$ & $\begin{array}{l}\text { Public private } \\
\text { should } \\
\text { started. }\end{array}$ \\
\hline & 45 & 15 & 20 \\
\hline
\end{tabular}

Source: Field survey, 2019

\section{CONCLUSION AND IMPLICATIONS}

This study analyzed the perception of the stakeholders toward resource mobilization in Rupandehi district. Using the questionnaire survey on purposive sample of 80 respondents representing government employees, former officials of LBs, representatives from civil societies and NGOs, and experts on fiscal decentralization and local development, the study reports that many of the stakeholders are not satisfied with the current local resources mobilization practices of Rupandehi district. As the study indicates, there is resource gap in local level to meet the aspiration and demand of people. The results also indicate that in order to mobilize effectively the local resources in development activities, the capacity of local 
bodies needs to be enhanced. The respondents further argued that role of political parties should be constructive for resource mobilization. Moreover, it is necessary to maintain transparency and inclusive participation in resource mobilization and decision making process.

With respect to the practices of internal resource mobilization by LBs, seventy five percent stakeholders indicate that they are not satisfied with the internal resource mobilization practiced by local bodies. With regard to revenue collection, all the stakeholders indicated that local bodies cannot collect the revenue according to the expectation. Similarly, vast majority of the stakeholder stated that role of political parties is not supportive at local level for the proper mobilization of resources.

This study attempted to shed a light on the perception of stakeholders in Rupandehi district on the current state of local resource mobilization. Findings from the study, based on

the opinion expressed by stakeholders, primarily imply that the capacity of local bodies needs to be enhanced for effective mobilization of resources at local level.

\section{REFERENCES}

Axin, G. H. (1978). New Strategies for Rural Development. Kathmandu: Rural Life Association, Nepal.

Boex, J., Heredia-Ortiz, E., Martinez-Vazquez, J., Timofeev, A., \& Yao, G. (2006). Fighting Poverty through Fiscal Decentralization. USA: United States Agency for International Development. Retrieved from http://www.fiscalreform.net.

District Development Committee (2015). District Development Programme, FY 2073/74 BS. Rupandehi: District Development Committee.

Jutting J., Elena C., \& Albrecht S. (2005). Decentralisation and poverty reduction. OECD Development Centre Policy Insight No. 5. Retrieved from www.oecd.org/dev/insights.

Lamichhane, H.R. (2011). Fiscal Federalism and Local Government Finance in Nepal. Unpublished M.Phil. Dissertation, Department of Economics, Tribhuvan University.

Sepulveda, C. F., \& Jorge Martinez-Vazquez, (2010). The Consequences of Fiscal Decentralization on Poverty and Income Inequality. International Studies Program Working Paper 10-02, February 2010, Andrew Young School of Policy Studies, Georgia State University. 